\title{
Induction training, career counselling, and performance review: views of junior medical staff
}

\author{
J G Williams, W Y Cheung
}

\begin{abstract}
Summary
Surveys of senior house officers and registrars were undertaken by postal questionnaire to ascertain views on the need for and content of induction training, career counselling, and performance review. The questionnaire was sent out in May 1990 and repeated in May 1996, after measures had been taken to improve induction training, and assessment and appraisal of trainees. In 1990 there was a clear wish to receive information on career prospects, research and education opportunities, and clinical audit, but more ambivalence regarding information or training in communication, discharge policies, standards, and encoding procedures. There was also a firm view that career counselling could be improved and formal goal setting and performance appraisal interviews would be welcomed. In 1996 there was disappointingly little change in the views expressed by the junior medical staff, though there was a significant increase in confidence in the role of the consultant in career counselling.
\end{abstract}

Keywords: induction training; career counselling; performance review; education

In 1990 we were concerned about the difficulties we had encountered in establishing formal arrangements for induction training, career counselling, and performance review for junior medical staff and felt it appropriate to seek the views of senior house officers (SHOs) and registrars on these issues. Following this survey, formal induction training was established for all doctors in training, taking place over one day in August and February at the beginning of each junior doctor intake. Greater involvement of consultants in career counselling and performance review was also encouraged, though formal procedures were not put in place. Six years after the first survey, the questionnaire was repeated to see if the views of junior doctors had changed as a result of the measures taken.

School of Postgraduate Studies in Medical \& Health Care,

Maes-y-Gwernen Hall, Morriston Hospital, Swansea SA6 6NL, Wales, UK

J G Williams

W Y Cheung

Accepted 16 December 1997 general hospitals in West Glamorgan. It was distributed in May 1990 and repeated in slightly modified version in May 1996. (Copies of the full survey are available from the corresponding author on request.) For both surveys, a reminder was sent to all those who had not replied after six weeks.

\section{METHOD OF ANALYSIS}

Each question in the survey offered three possible responses: 'yes', 'no' or 'indifferent'. We used the concept of 'valid per cent' to analyse the responses. This is the percentage of answers in each of these three categories, to each question, when missing or non-relevant answers have been excluded. We used this approach as the number of missing observations for all the major parameters was small. In addition, two questions had a set of sub-questions only for those who responded 'no'. Chi-square tests were performed, where appropriate, to see where the differences between 1990 and 1996 were statistically significant.

A major interest of the study was the type of information staff would like to receive at the beginning of their post. Information for this parameter was collected by a 13-item question. A principal component analysis ${ }^{1}$ with varimax rotation was performed to explain individual staff responses to the 13-item set with a relatively small number of factors. The principal component analysis was used to form uncorrelated linear combinations of the 13 observed variables. Each linear combination formed one component (or factor). The first component explained the maximum amount of variance in the set of the variables observed. Successive components explained smaller portions of the variance. Each of the observed variables would have a factor loading on all the extracted components. Final interpretation of the components depended on which observed variables had a high factor loading on which component. The varimax rotation was a technique to minimise the number of variables that had high factor loadings on each extracted components and would simplify the interpretation of the component. A factor was considered important if its 'eigenvalue' (a statistical measure of its power to explain variation between respondents) exceeded $1.1,{ }^{1}$ and it had face validity, that is, if it appeared 'at face value' to be measuring a recognisable aspect of the type of information junior staff would like to receive. 
Table 1 Comparison of responses

\begin{tabular}{|c|c|c|c|c|c|c|c|c|}
\hline & \multicolumn{3}{|c|}{$1990(\%)$} & \multicolumn{3}{|c|}{$1996(\%)$} & \multirow[b]{2}{*}{ Chi-Square } & \multirow[b]{2}{*}{$p$ value } \\
\hline & Yes & Indifferent & No & Yes & Indifferent & No & & \\
\hline $\begin{array}{l}\text { Communication } \\
\text { How to communicate with patients } \\
\text { How to communicate with relatives } \\
\text { How to communicate with GPs }\end{array}$ & $\begin{array}{l}18.1 \\
19.7 \\
21.1\end{array}$ & $\begin{array}{l}19.4 \\
18.3 \\
16.9\end{array}$ & $\begin{array}{l}62.5 \\
62.0 \\
62.0\end{array}$ & $\begin{array}{l}20.7 \\
25.4 \\
22.8\end{array}$ & $\begin{array}{l}17.1 \\
15.8 \\
14.9\end{array}$ & $\begin{array}{l}62.2 \\
58.8 \\
62.3\end{array}$ & $\begin{array}{l}0.2897 \\
0.8565 \\
0.1668\end{array}$ & $\begin{array}{l}0.8652 \\
0.6517 \\
0.9200\end{array}$ \\
\hline $\begin{array}{l}\text { Personal development } \\
\text { Career prospects } \\
\text { Research opportunities } \\
\text { Postgraduate activities }\end{array}$ & $\begin{array}{l}73.6 \\
56.9 \\
59.2\end{array}$ & $\begin{array}{l}6.9 \\
20.8 \\
11.3\end{array}$ & $\begin{array}{l}19.4 \\
22.2 \\
29.6\end{array}$ & $\begin{array}{l}68.7 \\
64.7 \\
59.3\end{array}$ & $\begin{array}{l}6.1 \\
12.1 \\
8.0\end{array}$ & $\begin{array}{l}25.2 \\
23.3 \\
32.7\end{array}$ & $\begin{array}{l}0.8440 \\
2.6619 \\
0.6537\end{array}$ & $\begin{array}{l}0.6557 \\
0.2642 \\
0.7212\end{array}$ \\
\hline $\begin{array}{l}\text { Individual patient management } \\
\text { Clinical policies } \\
\text { Admission and bed policies } \\
\text { Patient discharge policies }\end{array}$ & $\begin{array}{l}67.6 \\
57.1 \\
43.5\end{array}$ & $\begin{array}{l}7.0 \\
12.9 \\
10.1\end{array}$ & $\begin{array}{l}25.4 \\
30.0 \\
46.4\end{array}$ & $\begin{array}{l}70.5 \\
42.1 \\
36.2\end{array}$ & $\begin{array}{l}6.3 \\
14.9 \\
12.9\end{array}$ & $\begin{array}{l}23.2 \\
43.0 \\
50.9\end{array}$ & $\begin{array}{l}0.1780 \\
4.1016 \\
1.0471\end{array}$ & $\begin{array}{l}0.9149 \\
0.1286 \\
0.5924\end{array}$ \\
\hline $\begin{array}{l}\text { Liaison with hospital management } \\
\text { Key management personnel } \\
\text { How to communicate with managers }\end{array}$ & $\begin{array}{l}33.8 \\
32.4\end{array}$ & $\begin{array}{l}21.1 \\
22.5\end{array}$ & $\begin{array}{l}45.1 \\
45.1\end{array}$ & $\begin{array}{l}37.7 \\
32.2\end{array}$ & $\begin{array}{l}38.6 \\
20.9\end{array}$ & $\begin{array}{l}23.7 \\
47.0\end{array}$ & $\begin{array}{l}0.7577 \\
0.0911\end{array}$ & $\begin{array}{l}0.6847 \\
0.9555\end{array}$ \\
\hline $\begin{array}{l}\text { Information and monitoring } \\
\text { Diagnostic encoding procedures } \\
\text { Medical audit procedures }\end{array}$ & $\begin{array}{l}30.9 \\
45.1\end{array}$ & $\begin{array}{l}27.9 \\
18.3\end{array}$ & $\begin{array}{l}41.2 \\
36.6\end{array}$ & $\begin{array}{l}29.8 \\
49.1\end{array}$ & $\begin{array}{l}23.7 \\
17.2\end{array}$ & $\begin{array}{l}46.5 \\
33.6\end{array}$ & $\begin{array}{l}0.5915 \\
0.2956\end{array}$ & $\begin{array}{l}0.7440 \\
0.8626\end{array}$ \\
\hline
\end{tabular}

\section{Results}

In 1990,119 questionnaires were sent out, to which 73 replies were received (61\%), 46 from SHOs and 27 from registrars. In 1996, the number of junior staff in post had increased and 198 questionnaires were distributed, to which 118 replies were received $(59.6 \%), 85$ from SHOs and 33 from registrars. The analysis did not reveal any significant difference between the views of SHOs and registrars, or between the three hospitals. There were some differences between disciplines, which were largely explicable by the nature of the work undertaken. For example, anaesthetists were more likely to say 'no' to more information on admission and discharge policies, while accident and emergency SHOs had less interest in discharge policies, but were keen to understand more about admission policies. The sample size was not big enough to support formal statistical analysis of the differences in preferences between staff from different specialties. However, the pattern of response and the comments of the respondents showed a notable preference for specialty-based, rather than hospital-wide, induction training.

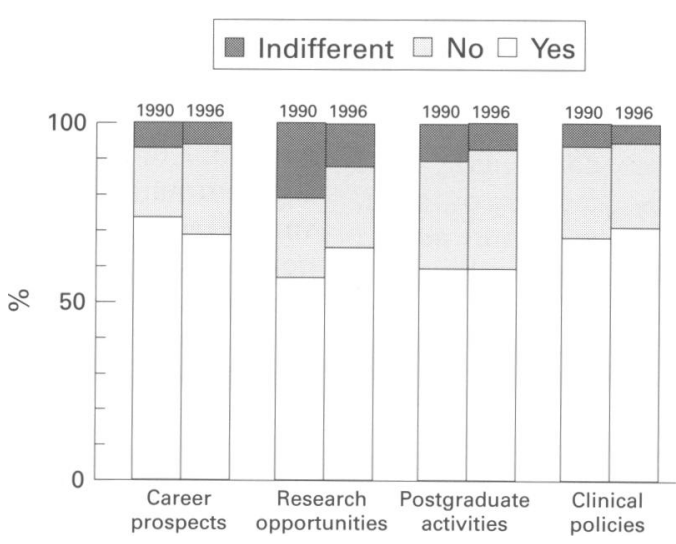

Figure 1 Responses to the question: When you started in this post, would it have been beneficial to you to have been given more information on career prospects, research opportunities, postgraduate activities, and clinical policies?
Between 1990 and 1996, there was no directly observable change in attitude by staff towards the type of information they would like to receive at the beginning of their post. An item-by-item comparison of the 13-item set by the chi-square test showed no significant difference between the 1990 and the 1996 group in any of the 13 items (table 1 ).

The majority of both the 1990 and the 1996 groups did not think it beneficial to be given more information at their induction on how to communicate with patients, relatives, general practitioners and managers. By contrast, analysis of respondents' free text comments showed that, although they did not feel the need for information on communication applied to them individually, communication was an important topic in general.

The majority of both the 1990 and the 1996 groups would have liked to have had more information on career prospects, postgraduate activities, research opportunities and clinical policies (figure 1 ).

Analysis of respondents' comments showed that there was a general desire for more advice and guidance on career progression. There was a demand for more structured and specialtybased guidance and a dissatisfaction with the passive way in which career advice was provided in the current system, especially from SHOs, as illustrated by the following quotes.

One SHO suggested structured career guidance provided through formal channels:

"Currently, most information is got from colleagues and consultants. I think a more progressive advice service, starting in medical school with follow-up throughout career would be better."

A dissatisfaction with the current level of guidance and a desire for more specialty-based career advice was illustrated by the following quote:

"The only advice I've been given by educational supervisor is 'Pass the exam!'. It would be useful to know who could provide specific specialty career advice locally and regionally."

One SHO queried the educational merits of his current post and bemoaned the passive way 


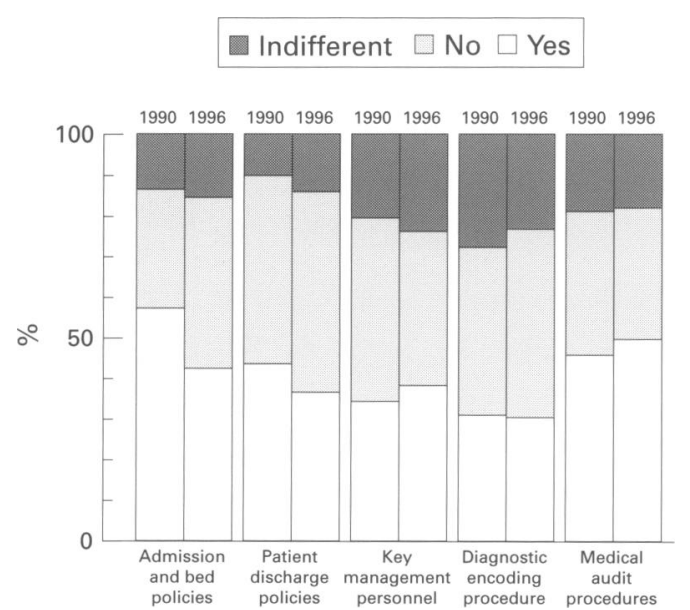

Figure 2 Responses to the question: When you started in this post, would it have been beneficial to you to have been given more information on admission and bed policies, patient discharge policies, key management personnel, diagnostic encoding procedures, and medical audit procedures?

in which career advice was provided in the current system.

"There is little emphasis placed on SHO experience..., and very little opportunity to express what the individual hopes to gain from a particular job. Career advice is available but you have to seek out the appropriate person yourself and organise a meeting. Generally speaking, consultants are helpful when approached but there is very little spontaneous input from them."

Table 2 Results of factor analysis to explain variations in responses in 1990

\begin{tabular}{lll}
\hline & $\begin{array}{l}\text { Items with high factor loading on each of the } \\
\text { factors }\end{array}$ & $\begin{array}{l}\text { \% of variation } \\
\text { explained }\end{array}$ \\
\hline Factor 1 & $\begin{array}{l}\text { How to communicate with patients } \\
\text { Communication }\end{array}$ & 24.7 \\
& $\begin{array}{l}\text { How to communicate with relatives } \\
\text { How to communicate with managers } \\
\text { How to communicate with GPs } \\
\text { Factor 2 }\end{array}$ & \\
Monitoring and management & $\begin{array}{l}\text { Kedical audit procedure } \\
\text { Clinical policies } \\
\text { Diagnostic encoding procedures } \\
\text { Postgraduate activities } \\
\text { Factor 3 } \\
\text { Personal development }\end{array}$ & 15.6 \\
Factor 4 & $\begin{array}{l}\text { Research opportunities } \\
\text { Patient discharge policies } \\
\text { Andividual patient management }\end{array}$ & 12.0 \\
\hline
\end{tabular}

Table 3 Results of factor analysis to explain variations in responses in 1996

\begin{tabular}{|c|c|c|}
\hline & $\begin{array}{l}\text { Items with high factor loading on each of } \\
\text { the factors }\end{array}$ & $\begin{array}{l}\% \text { of variation } \\
\text { explained }\end{array}$ \\
\hline $\begin{array}{l}\text { Factor } 1 \\
\text { Communication }\end{array}$ & $\begin{array}{l}\text { How to communicate with relatives } \\
\text { How to communicate with patients } \\
\text { How to communicate with GPs }\end{array}$ & 23.5 \\
\hline $\begin{array}{l}\text { Factor } 2 \\
\text { Personal development }\end{array}$ & $\begin{array}{l}\text { Research opportunities } \\
\text { Career prospects } \\
\text { Postgraduate activities }\end{array}$ & 15.1 \\
\hline $\begin{array}{l}\text { Factor } 3 \\
\text { Individual patient management }\end{array}$ & $\begin{array}{l}\text { Patient discharge policies } \\
\text { Admission and bed policies } \\
\text { Clinical policies }\end{array}$ & 11.9 \\
\hline $\begin{array}{l}\text { Factor } 4 \\
\text { Liaison with hospital management }\end{array}$ & $\begin{array}{l}\text { How to communicate with managers } \\
\text { Key management personnel }\end{array}$ & 9.4 \\
\hline $\begin{array}{l}\text { Factor } 5 \\
\text { Information and monitoring }\end{array}$ & $\begin{array}{l}\text { Diagnostic encoding procedure } \\
\text { Medical audit procedure }\end{array}$ & 8.7 \\
\hline
\end{tabular}

A dissatisfaction with the educational merit of their current post were reflected in comments by other respondents, and some were dissatisfied with the arrangements for study leave. There was anxiety about the impact of the Calman reforms on training as illustrated by the following quote:

"I am in a career post that will take me to accreditation but no-one knows how the rotation will proceed because of introduction of Calman!'

This anxiety about Calman was found in five out of the seven registrars who had made freetext comments in their questionnaires.

There was less interest in learning about admission and bed policies, patient discharge policies, key management personnel, diagnostic encoding procedures, and medical audit procedures (figure 2). There was a noticeable trend for the answers to these questions to relate to the appropriateness of the specialty.

Nevertheless, the factor analysis found some subtle changes in the inter-relationships of the items about the type of information staff would like to receive at the beginning of their post between 1990 and 1996. Four underlying dimensions were identified from the 1990 findings, which would be able to explain most $(61.7 \%)$ of the variations in staff response (table 2).

Thus, factor analysis for the 1990 group showed that staff response to the type of information they would like to receive at the beginning of their post could be broadly summarised by their attitude towards the four factors: communication; monitoring and management; personal development; and individual patient management. By contrast, five underlying dimensions were identified from the 1996 findings which would be able to explain most $(68.6 \%)$ of the variations in staff response (table 3 ). These five factors could be broadly summarised as: communication, personal development, individual patient management, liaison with hospital management, and information and monitoring.

This represents a change in attitude of junior staff. In 1990, the items on how to communicate with patients, relatives, general practitioners and managers were related to each other. However, in 1996, the item how to communicate with managers no longer related to the other three items about communication. Instead, this item was inter-related with the item about key management personnel to form an independent factor. Liaison with hospital management had become, for the juniors in 1996, an element worthy of consideration in its own right. Furthermore, the items about medical audit procedures and diagnostic encoding procedures were no longer related to the same factor with the items key management personnel and clinical policies in 1996. The only dimension which remained unchanged was the factor of personal development, which included education, research and career prospects. These changes were consistent with recent developments in the NHS, such as the introduction of general management and the emphasis on medical audit. 


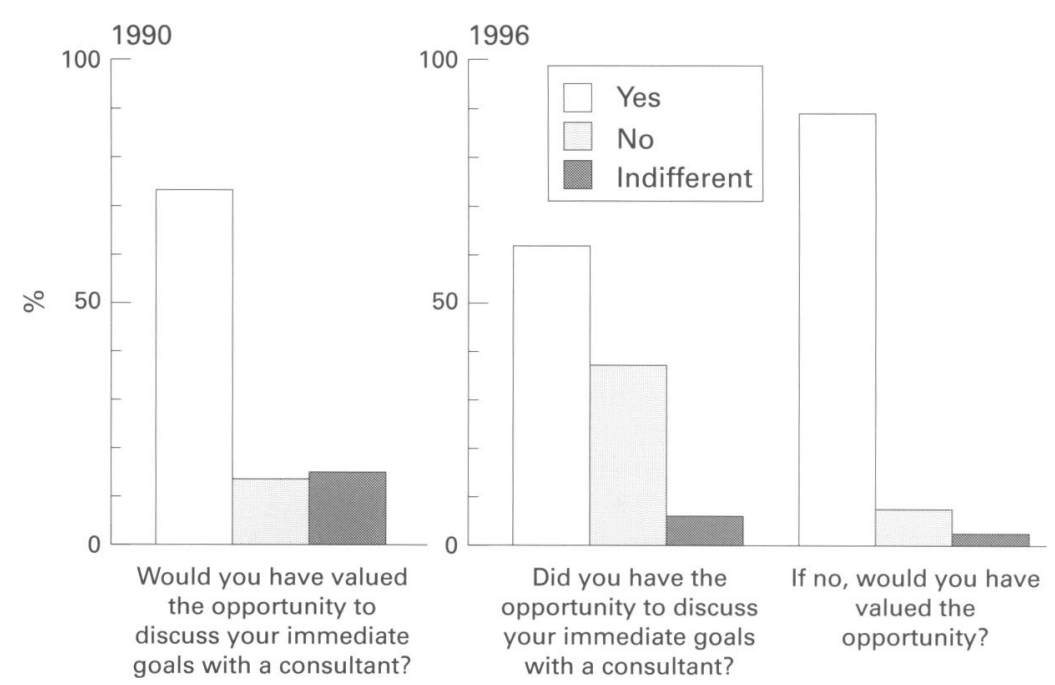

Figure 3 Responses to the question: When you started in this post: 1990: Would you have valued the opportunity to discuss your immediate goals with a consultant? 1996: Did you have the opportunity to discuss your immediate goals with a consultant? If no, would you have valued the opportunity?

The majority of 1990 respondents (73\%) would have valued an opportunity to discuss their immediate goals in terms of experience and training. There was still a substantial number of the 1996 group (36\%) who did not have this opportunity (figure 3 ).

Towards the end of their time in post, $83.6 \%$ of the 1990 group and $86.3 \%$ of the 1996 group would have liked to be given advice regarding their next move. There was no statistically significant difference between the two groups in this. The percentage of staff who would like to discuss goal achievement in terms of training and experience in $1996(85.2 \%)$ was higher than that of $1990(76.1 \%)$, but the difference did not reach statistical significance. The percentage of staff who would like to receive a formal performance review in 1996 $(78.3 \%)$ was also higher than that of 1990 $(68.5 \%)$, but again, the difference did not reach statistical significance.

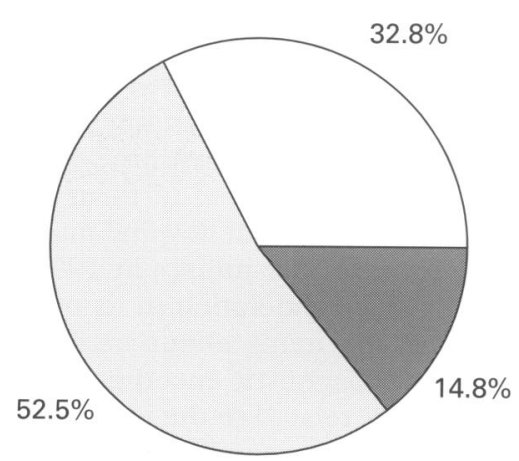

1990

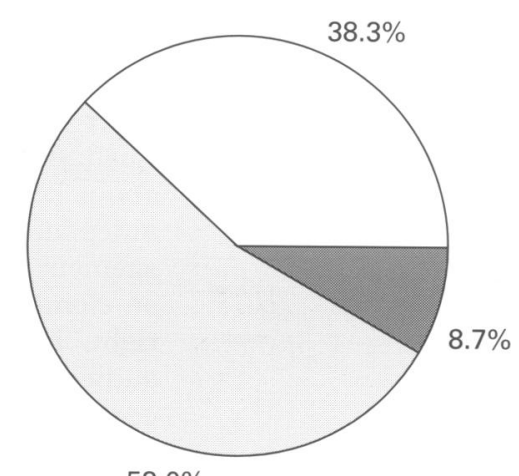

$53.0 \%$
Yes $\square$ No $\square$ Indifferent

Figure 4 Percentage of staff who felt that career counselling was adequate. When asked with whom they would like a formal, arranged interview, there was no clear preference between their consultant, the postgraduate organiser or the specialty tutor, though a non-significant increase in confidence in the consultant and specialty tutor was apparent between 1990 and 1996 (figure 5)

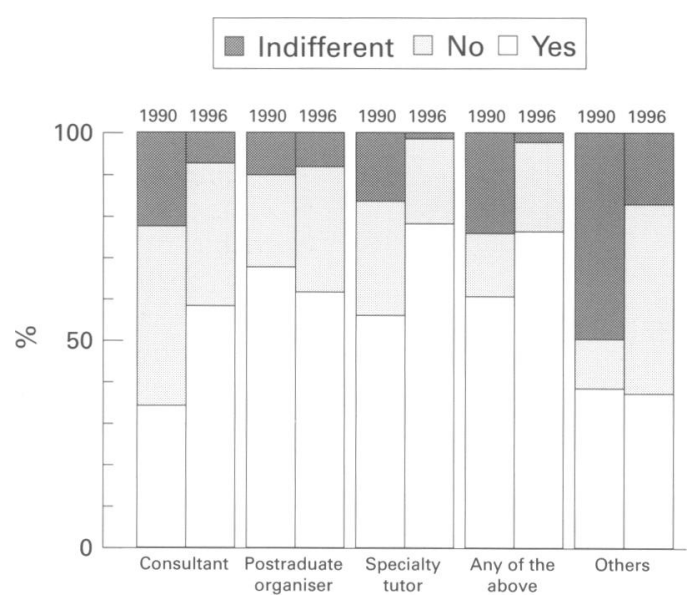

Figure 5 Person with whom staff would like formal, arranged interview

About half of the respondents in both the $1990(52.5 \%)$ and the 1996 group (53.0\%) did not feel that the career counselling they were currently receiving was adequate (figure 4). There was no statistically significant change in this aspect between the two groups.

In summary, there were no significant changes between 1990 and 1996 in terms of most of the parameters with regard to career counselling. There were some changes of staff attitude to the type of information they would like to receive at the beginning of their post. These changes were largely confined to the inter-relationships of some parts of the service component of their post. Their attitude towards the training component remained largely unchanged.

\section{Discussion}

The first survey in 1990 was undertaken against a background of major change to the staffing $^{2}$ and organisation ${ }^{3}$ of the health service, and the knowledge that the introduction of formal career counselling and performance review was much needed, ${ }^{4}$ as was formal induction training. The results of the first survey confirmed that there was a need for change in the form of formal induction training and encouragement of consultants to be more proactive in meeting the appraisal needs of their junior staff. There has, however, been disappointing progress, as judged by these views of junior staff.

Although formal induction training was introduced after the first questionnaire, it would appear that this is inappropriately targeted and it may well be that it would be more appropriately delivered on a specialty basis. The replies to both questionnaires indicate an indifference to advice on discharge policies, standards for discharge summaries and encoding procedures, which suggested a degree of complacency in areas where it is widely believed there is room for improvement. A perceived need for further information on admission and bed policies probably reflects the local difficulties that junior medical staff encounter in finding beds for acute admissions. 
The rejection by many junior doctors of induction training in communication, discharge polices and encoding procedures does not reflect the known problems in these areas, and suggests that attitudes, as well as knowledge and skills, need to be addressed in order to achieve improvements. Present arrangements for induction training, which are hospital-wide and look largely at process measures relating to the delivery of healthcare, do not meet all the needs of doctors in training when they start an appointment. These issues remain highly topical ${ }^{56}$ and further effort is clearly required to effect adequate change. It could be argued that some of these issues could be covered in more depth in undergraduate

1 Jollife IT, Morgan BJ. Principal component analysis and exploratory factor analysis. Stat Meth Med Res 1992;1:6995.

2 Department of Health \& Social Security. Hospital medical staffing: achieving a balance. London: DHSS, 1986.

3 Department of Health \& Social Security. Working for patients. London: HMSO, 1989.

4 Garrud P. Counselling needs and experience of junior doctors. $B M \mathscr{f} 1990 ; 300: 445-57$. training, for example, the need for better undergraduate training in communication issues has already been suggested by the General Medical Council.

A striking finding from these two surveys is that there remains a clear wish from junior staff for performance review and career counselling, and this need is not yet being met. A large majority of respondents wished to receive more formal goal-setting interviews at the beginning of an appointment and performance review later. This will be introduced as a formal process for specialist registrars under the implementation of the Calman reforms, but is not formally in place for SHOs, who also wish to receive it.

5 Cantwell BM, Ramirez AJ. Doctor-patient communication: a study of junior house officers. Med Educ 1997;31:17-21.

6 Spencer J, Stacy R. Interpersonal skills are being taught better, but more work is needed (letter). BMF 1997:314:1203.

7 George C, ed. The new doctor. London: General Medical Council, April 1997.

\section{Images in medicine}

\section{Retroperitoneal haematoma}

A 77-year-old woman was admitted with unstable angina. She was treated with intravenous heparin in addition to other anti-anginal medication. On the fifth day of admission, her blood pressure suddenly dropped and she went into hypotensive shock. Abdominal examination revealed a diffuse tender swelling in the left illiac fossa. Investigations showed moderate renal impairment and a $5 \mathrm{~g} / \mathrm{dl}$ fall in her haemoglobin since admission. There was no evidence of overt bleeding and coagulation screen remained normal. A computed tomographic scan of the abdomen revealed two separate retroperitoneal haematomata (two continuous lines marked 1 and 2 on the figure).

Heparin was stopped and she was resuscitated with a blood transfusion. She made an uneventful recovery and was discharged home.

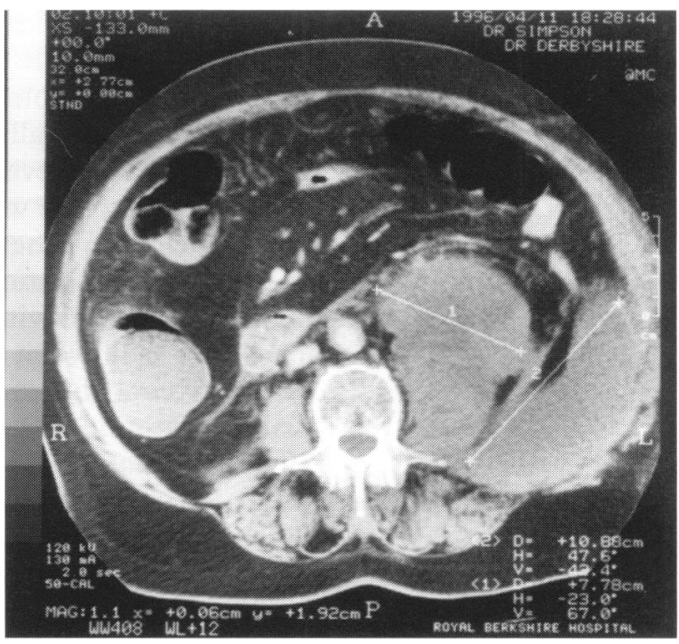

MANSOOR AHMED Department of Geriatrics, Poole Hospital NHS Trust, Poole, Dorset BH15 2HP, UK

H SIMPSON

Royal Berkshire Hospital, Reading, Berkshire RG1 5AN, UK 